\title{
Two new species of the genus Carpelimus Leach, 1819 from Malaysia (Coleoptera: Staphylinidae: Oxytelinae)
}

\author{
Ава новых вида рода Carpelimus Leach, 1819 из Малайзии \\ (Coleoptera: Staphylinidae: Oxytelinae)
}

\author{
M.Yu. Gildenkov \\ М.Ю. Гицьденков
}

Smolensk State University, Przhevalsky str. 4, Smolensk 214000, Russia. E-mail: mgildenkov@mail.ru
Смоленский государственный университет, ул. Пржевальского 4, Смоленск 214000, Россия.

KEY WORDS: Coleoptera, Staphylinidae, Carpelimus, new species, Oriental region, Malaysia.

КЛЮЧЕВЫЕ СЛОВА: Coleoptera, Staphylinidae, Carpelimus, новые виды, Восточная биогеографическая область, Малайзия.

ABSTRACT: Two new species of genus Carpelimus are described from the Malaysia: Carpelimus (s. str.) pulchrus, sp.n. and Carpelimus (Bucephalinus) fereus, sp.n.

РЕЗЮМЕ: Описываются два новых вида рода Carpelimus из Малайзии: Carpelimus (s. str.) pulchrus, sp.n. и Carpelimus (Bucephalinus) fereus, sp.n.

This study is a continuation of the previous studies on the genus Carpelimus for the Oriental biogeographic region [Gildenkov, 2015, 2018, 2019a, c].

This paper is based on the specimens deposited in the following collections: $\mathrm{cMG}$ - private collection of $\mathrm{M}$. Gildenkov (Smolensk, Russia); cPB — private collection of Petr Baňař (Strážnice, Czech Republic); MHNG - Muséum d'Histoire Naturelle, Genève (Suisse); MMBC - Moravian Museum in Brno Collection (Czech Republic). In the present study, standard methods were used for the taxonomic research of insects; the preparations were made on an MBS-10 binocular microscope. The genital preparations were processed using $10 \% \mathrm{KOH}$ and then fixed in euparal. In the descriptions and diagnoses giving the length to width ratio for the head, pronotum, and elytra, the following standard units were used: 7 standard units $=0.1 \mathrm{~mm}$; thus, 1 standard unit constitutes about $0.0143 \mathrm{~mm}$. Photographs were taken with a Canon EOS 5D Mark III camera and a Canon MPE $65 \mathrm{~mm}$ objective using the extended focus technology.

Carpelimus (s.str.) pulchrus Gildenkov, sp.n. Figs 1-4.

MATERIAL. Holotype, $\sigma^{7}$, West Malaysia, Perak: with labels "W.MALAYSIA FELDA LASAH vill. env. 40 km NE of IPOH 13-21.iii.2001 R.Hergovits leg." (MMBC). Paratypes: 18 우 "W.MALAYSIA FELDA LASAH vill. env. 40 km NE of IPOH 13.-21.iii.2001 R.Hergovits leg." (cPB; 2 + - MMBC; 5 ㅇ - cMG).

DESCRIPTION (holotype). Length $3.0 \mathrm{~mm}$. Body colouration dark brown, with red tint; legs and antennae light brown. Integument slightly shining, body surface with short light- coloured hairs.

Head transverse, with a wide base, ratio of its length (from posterior margin of head to anterior margin of clypeus) to maximum width about 23:38. Neck constriction prominent. Eyes large, convex, occupying almost entire lateral surface of head; temples weakly developed, eye diameter in dorsal view about 3 times as long as temple length (Figs 1-2). Head surface with very delicate, extremely fine and dense punctation. Puncture diameter more than 5 times as small as eye facet. Distances between punctures significantly smaller than their diameter, interspaces smooth, slightly shining. Antennae not completely preserved in holotype (Fig. 1), only 4 and 5 first segments present on left and right antennae, respectively. In paratype (female) antennae similar in morphology (Figs 1-2), with length of all segments significantly exceeding their width (Fig. 2). Pronotum heart-shaped (Figs $1-2$ ), widest about $2 / 3$ its length from base, then narrowed. Lateral margins serrated (Figs 1-2). Ratio of pronotum length to its maximum width about 33:49. Surface of central part of pronotum with very delicate, extremely fine and dense punctation, near lateral margins surface of pronotum densely shagreened. Puncture diameter more than 5 times as small as eye facet. Distances between punctures significantly smaller than their diameter, interspaces smooth, slightly shining. Pronotal disc with two pronounced symmetrical longitudinal parallel depressions and 1 weak unpaired depression along midline near apex (Figs 1-2).

Ratio of length of elytra to their combined width about 52:56. Elytra with weak longitudinal depressions along suture (Figs 1-2). Surface of elytra with rather delicate, fine and dense punctation. Puncture diameter about 1.5 times as small

How to cite this article: Gildenkov M.Yu. 2019. Two new species of the genus Carpelimus Leach, 1819 from Malaysia (Coleoptera: Staphylinidae: Oxytelinae) // Russian Entomol. J. Vol.28. No.4. P.370-372. doi: 10.15298/ rusentj.28.4.04 
as eye facet. Distances between punctures significantly smaller than their diameter, interspaces smooth, slightly shining.

Abdomen delicately shagreened.

Aedeagus of characteristic structure (Fig. 3).

Female. Sexual dimorphism absent, female morphologically similar to male. Spermatheca of characteristic structure (Fig. 4).

COMPARATIVE REMARKS. The new species is similar in size to Carpelimus (s. str.) magnus Gildenkov, 2014 that lives in Indonesia and Philippines [Gildenkov, 2014c, 2019b], but differs from this species in having a lighter colouration, slightly more pronounced temples, wider prono-
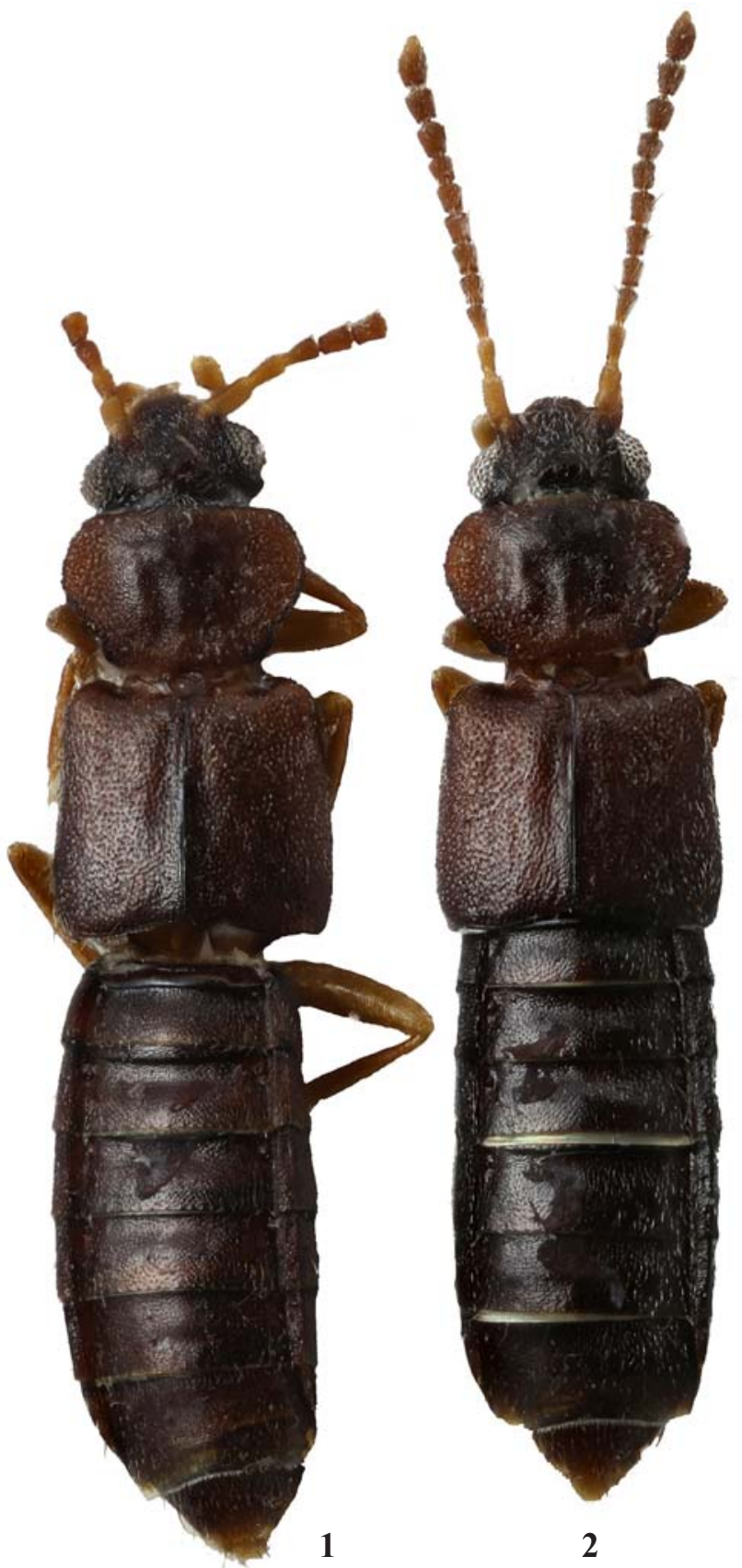

Figs 1-2. Carpelimus (s. str.) pulchrus, sp.n., dorsal view: 1 holotype, male; 2 - paratype, female.

Рис. 1-2. Carpelimus (s. str.) pulchrus, sp.n., сверху: 1 глотип, самец; 2 - паратип, самка. tum with serrated lateral margins and elytra with a significantly finer punctation; clearly differs in the structure of the aedeagus (Fig. 3).

DISTRIBUTION. Malaysia: Malacca.

ETYMOLOGY. From Latin "pulchram, pulchrå” (beautiful, fine); the name refers to the external appearance of the beetle: its large size, a rather bright colouration and wide pronotum with serrated margins.

\section{Carpelimus (Bucephalinus) fereus Gildenkov, sp.n.} Figs 5-7.

MATERIAL. Holotype, $\sigma^{\top}$, Malaysia, Borneo: with labels "SABAH: Crocker Ra. 1270 m, km 60 rte Kota Kinabalu-Tambunan 17.V.1987 Burckhardt - Löbl” (MHNG).

DESCRIPTION (holotype). Length $1.8 \mathrm{~mm}$. Colouration brown, legs and antennae yellow brown. Integument slightly shining, body with short, light-coloured hairs.

Head transverse, with a wide base, ratio of its length (from posterior margin of head to anterior margin of clypeus) to maximum width about 16:24. Neck constriction prominent. Eyes small, convex. Temples well-developed, round, eye diameter in dorsal view significantly (about 1.5 times) smaller than temple length. Head widest across temples (Fig. 5). Head surface with extremely delicate, very fine and dense punctation. Puncture diameter about 4.0 times as small as eye facet. Distances between punctures slightly smaller than their diameter, interspaces smooth, slightly shining. Antennae rather long, antennal segments 1-3 and 5 elongated; segments 4 and 67 slightly elongated; segments $8-10$ about as long as wide; segment 11 elongated, conical. Last 3 segments more massive than others and form loose club (Fig. 5).

Pronotum widest about $2 / 3$ its length from base, then narrowed. Lateral margin smoothly rounded (Fig. 5). Ratio of pronotum length to its maximum width about 19:26. Surface of pronotum with extremely delicate, very fine and dense punctation. Puncture diameter about 4.0 times as small as eye facet. Distances between punctures slightly smaller than their diameter, interspaces smooth, slightly shining. Pronotal disc with 2 pairs of prominent, symmetrical depressions merging across midline into 2 depressions (horseshoe-shaped near base and butterfly-shaped in central part of disc) and with 1 small, unpaired, oval depression apically along midline (Fig. 5).

Ratio of length of elytra to their combined width about 27:32. Scutellum with weak, round depressions (Fig. 5). Surface of elytra with extremely delicate, very fine and dense punctation. Puncture diameter about 3.0 times as small as eye facet. Distances between punctures slightly smaller than their diameter, interspaces smooth, slightly shining.

Abdomen delicately shagreened.

Aedeagus of characteristic structure (Figs 6-7).

Female. Unknown.

COMPARATIVE REMARKS. The new species is very similar in colouration, body morphology, punctation patterns and depressions on the pronotal disc with species of the "silvestris" group [Gildenkov, 2014a, b; 2015; 2019a] and can belong to this group. It differs from Carpelimus silvestris (Cameron, 1918) and C. pseudosilvestris Gildenkov, 2014 that share the same habitats with the new species on Borneo in having shorter antennae and a slightly smaller body size. It can also be distinguished from $C$. pseudosilvestris by the shape of the depressions on the pronotum and from $C$. silvestris by more rounded temples. The new species clearly differs from all species of the "silvestris" group [Gildenkov, 2015: p.377, Figs 7, 9-10, 12; p.378, Figs $1,3,5)$ in the structure of the aedeagus (Figs 6-7).

DISTRIBUTION. Malaysia: Borneo. 

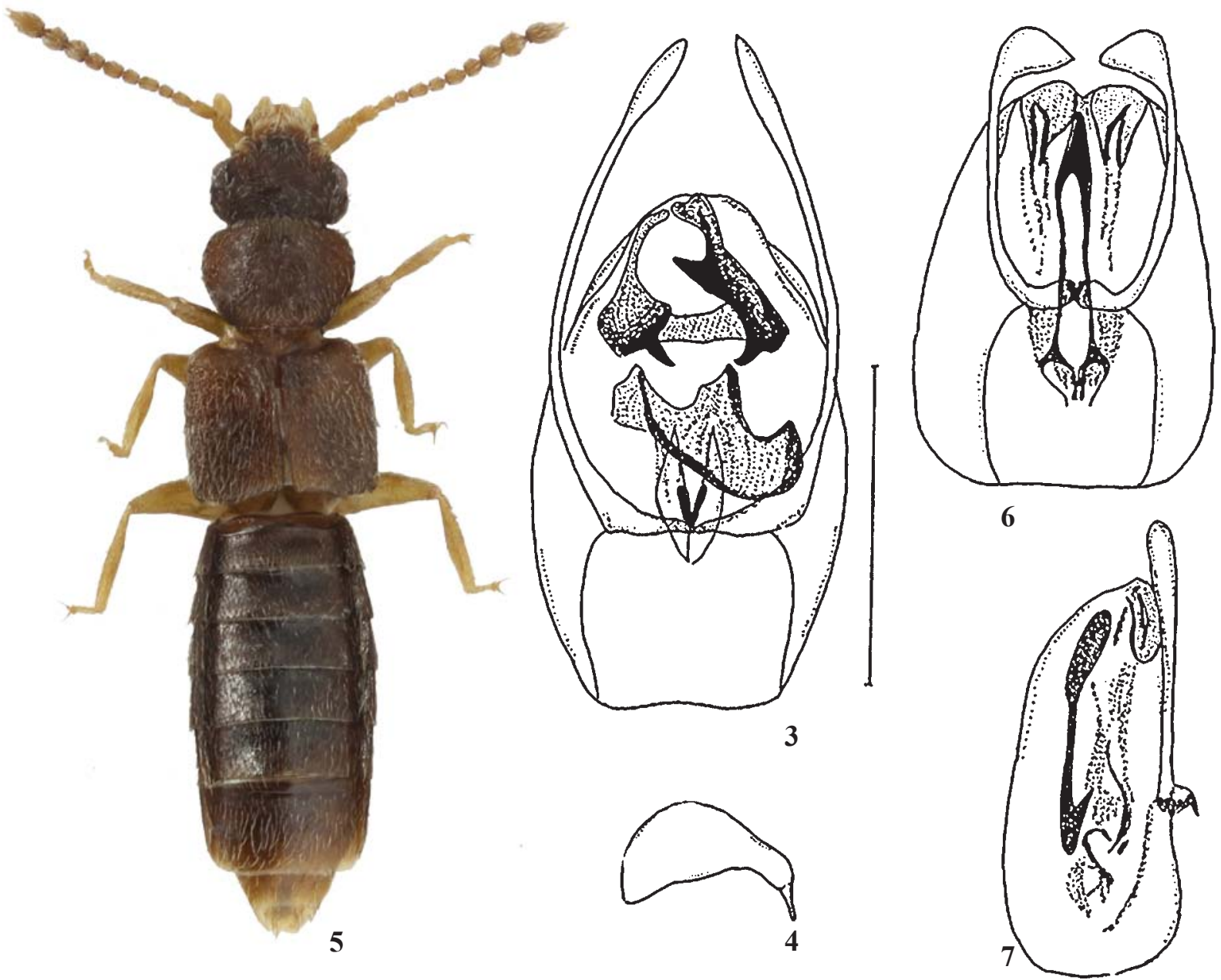

Figs 3-7. Carpelimus spp.: 3 - C. pulchrus, sp.n., holotype, aedeagus, ventral view; 4 - C. pulchrus, sp.n., paratype, spermatheca; 5 - C. fereus, sp.n., holotype, male, dorsal view; 6 - C. fereus, sp.n., holotype, aedeagus, ventral view; 7 - C. fereus, sp.n., holotype, aedeagus, lateral view. Scale bar (Figs 3-4, 6-7): $0.25 \mathrm{~mm}$.

Рис. 3-7. Carpelimus spp.: $3-$ C. pulchrus, sp.n., голотип, эдеагус, снизу; $4-$ C. pulchrus, sp.n., паратип, сперматека; $5-C$. fereus, sp.n., голотип, самец, сверху; $6-$ C. fereus, sp.n., голотип, эдеагус, снизу; 7 - C. fereus, sp.n., голотип, эдеагус, сбоку. Масштаб (Рис. 3-4, 6-7): 0,25 mm.

ETYMOLOGY. From Latin "fere" (approximately, almost); the name refers to a significant similarity of the new species to C. silvestris and C. pseudosilvestris.

Acknowledgements. The author wishes to thank all colleagues for making material available for study: Petr Baňar (MMBC) and Giulio Cuccodoro (MHNG). I also thank Kirill Makarov for taking the photographs (Moscow Pedagogical State University, Russia).

\section{References}

Gildenkov M.Yu. 2014a (2013). [New species of the genus Carpelimus Leach, 1819 from the "silvestris" and "taprobanae" species groups (Coleoptera, Staphylinidae, Oxytelinae)] // Izvestiya Smolenskogo Gosudarstvennogo Universiteta. No.4(24). P.292-305 [in Russian, with English summary].

Gildenkov M.Yu. 2014b. [Five new species of the genus Carpelimus Leach, 1819 from the Oriental Region and Palaearctic (Coleoptera, Staphylinidae, Oxytelinae)] // Izvestiya Smolenskogo Gosudarstvennogo Universiteta. No.2(26). P. 232-244 [in Russian, with English summary].
Gildenkov M.Yu. 2014c. [New species of the genus Carpelimus Leach, 1819 from Borneo, Philippines and Sulawesi (Coleoptera: Staphylinidae: Oxytelinae)] // Izvestiya Smolenskogo Gosudarstvennogo Universiteta. No.3(27). P.183-195 [in Russian, with English summary].

Gildenkov M.Yu. 2015. [Fauna of Carpelimus of the Old World (Coleoptera: Staphylinidae)]. Smolensk: SmolSU. 414 pp. [In Russian, with English summary]

Gildenkov M.Yu. 2018. Five new species of the genus Carpelimus Leach, 1819, from the Oriental region (Coleoptera: Staphylinidae: Oxytelinae) // Russian Entomological Journal. Vol.27. No.2. P.135-142.

Gildenkov M.Yu. 2019a. Five new species of the Genus Carpelimus Leach, 1819 from Thailand and the Philippines (Coleoptera: Staphylinidae: Oxytelinae) // Russian Entomological Journal. Vol.28. No.1. P.30-35.

Gildenkov M.Yu. 2019b. [The new data on distribution Carpelimus Leach, 1819 (Coleoptera, Staphylinidae) in Oriental Region] // Vestnik nauchnyh konferentsii. 4-2(44). Teoreticheskie i prikladnye voprosy nauki i obrazovaniya. Tambov: Jukom. P.31-33. [in Russian, with English summary].

Gildenkov M.Yu. 2019c. Seven new species of the Genus Carpelimus Leach, 1819 from the "taprobanae" group (Coleoptera: Staphylinidae: Oxytelinae) // Russian Entomological Journal. Vol.28. No.2. P.138-145. 